\title{
A Teologia do Mistério: aspectos bíblico-patrísticos, teológico-litúrgicos e magisteriais
}

\author{
Orientador: Luiz Fernando Ribeiro Santana \\ Mestrando: Vitor Gino Finelon \\ Área de Concentração: Teologia Sistemático-Pastoral
}

Linha de Pesquisa: Fé e Cultura

A palavra "mistério", nascida dentro do ambiente cultual grego, entrou na Sagrada Escritura já nas traduções do Antigo Testamento em relação aos termos "râz" e "sôd", respectivamente, em aramaico e hebraico, recebendo assim uma carga semântica teológica dentro das concepções do Povo da primeira Aliança. Por conseguinte, o Novo Testamento, sobretudo as cartas paulinas, faz um abundante uso do termo mistério. Numa linha progressiva de elaboração do conceito de mistério na Sagrada Escritura, ele é a revelação do plano salvífico de Deus Pai em Jesus Cristo através de etapas sucessivas e concatenadas. A teologia patrística, recebendo da tradição bíblica o conceito de mistério, vai desenvolvê-lo quanto as suas mediações no momento eclesial em quatro direções interdependentes: a História Salvífica, a Igreja, a Palavra de Deus e a liturgia. Na primeira metade do século XX, em virtude do afastamento da teologia das fontes bíblico-patrísticas, o monge beneditino Odo Casel reintroduzirá na reflexão teológico-litúrgico o conceito de mistério, recuperando seu vigor fontal. Esta recuperação, apesar de sofrer uma série de críticas, paulatinamente vai sendo incorporada nos documentos magisteriais. Neste movimento, a Constituição Dogmática Sacrosanctum Concilium é o documento basilar e paradigmático na reintrodução da Teologia do Mistério pela Igreja. De fato, as intuições mistéricas dos Padres conciliares recolhidas neste documento vão sendo desenvolvidas nas demais Constituições do Concilio Vaticano II, legando a Igreja de hoje uma fecunda herança para repensar sua prática teológico-pastoral.

Palavras-chave: Teologia litúrgica. Teologia do mistério. Sagrada Escritura. 